\title{
PELAKSANAAN KELAS IBU HAMIL DENGAN \\ KEMANDIRIAN IBU PRIMIPARA DALAM PERAWATAN NEONATUS DI PUSKESMAS SUKORAME KOTA KEDIRI
}

\author{
Shinta Kristianti ${ }^{*}$ Ari Kusmiwiyati ${ }^{* *}$ \\ *)Poltekkes Kemenkes Malang, Prodi D-IV Kebidanan Kediri \\ **)Poltekkes Kemenkes Malang, Prodi D-IV Kebidanan Malang
}

Korespondensi: Shinta4300@yahoo.co.id

\begin{abstract}
A woman who suffered on first pregnancy, often do not know how to care for the baby later. Parents of babies are considered inadequate in providing care to the baby. Antenatal Class means to learn together about the health of pregnancy, midwives can teach and support the mothers to care of her baby. This research aimed to know the relationship class implementation with primiparas's autonomy in neonatal care. The design was an analytic correlation with cross sectional approach. The population was 35 primigravidas with gestational age of 29-36 weeks on Puskesmas Sukorame Kediri. Sampling technique used was purposive sampling. The samples were 22 respondents who met the inclusion criteria. Test data analysis using Fisher exact test with a significance of $5 \%$. Based on the results count by probablity fisher exact test for $\alpha$ error level of 5\% (0.05) was obtained $\mathrm{p}$ (count) 0.054 greater than 0.05 . It can be concluded that the $\mathrm{p}$ (count) is greater than the specified error level, so $\mathrm{H}-0$ accepted, which means there was no correlation of Antenatal Class Implementation to Primipara's Autonomy in Neonatus Care.
\end{abstract}

Keywords: Pregnancy Class, autonomy, primigravida, primipara, Neonatus

\section{PENDAHULUAN}

Program pembangunan kesehatan di Indonesia dewasa ini masih diprioritaskanpada upaya peningkatan derajat kesehatan ibu dan anak yang dipantausecaraberkesinambunganmelalui Angka Kematian Ibu (AKI) dan Angka Kematian Bayi(AKB).

Dari semua target MDGs, kinerja penurunan angka kematian ibu secara global masih rendah. Di Indonesia, telahterjadipenurunan AKI menjadi228 per 100.000 kelahiran hidup pada tahun 2007. Namun demikian, target pencapaian MDGs pada tahun 2015 adalah sebesar 102 per 100.000 kelahiran hidup, sehingga diperlukan upaya yang lebih keras untuk mencapai target tersebut. Walaupun pelayanan antenatal dan pertolongan persalinan oleh tenaga kesehatan telah menunjukkan peningkatan yang cukup signifikan, namun adanya beberapa kendala seperti temuan resiko tinggi pada ibu hamil dan aborsi perlu mendapat perhatian. Berdasarkan data diatas diketahui bahwa target penurunan AKI di Indonesia bahkan belum mencapai setengah dari angka yang diharapkan (BAPPENAS, 2010).

Penyebab tingginya AKI dan AKBjuga disebabkan karena ketidak berdayaan seorang ibu dalam pengambilan keputusan untuk mendapatkan pertolongan medis. Hal ini disebabkan oleh beberapa faktor, diantaranya adalah rendahnya pengetahuan ibu dalam perawatan kesehatan ibu dan bayi, serta pengenalan tanda-tanda bahaya obstetri dan neonatal sehingga terlambat dalam pengambilan keputusan (Kemenkes, 2012).

Seorang perempuan yang mengalami kehamilan pertama (primigravida), 
seringkali tidak mengetahui bagaimana cara merawat kehamilan, belum mempunyai pengalaman tentang persalinan, serta tidak tahu apa yang harus dilakukan setelah bayinya lahir. Dalam budaya suku Jawa, orang tua dari calon ibu selalu ikut berperan dalam perawatan bayi. Calon ibu dianggap tidak tahu, tidak akan mampu serta belum berpengalaman dalam memberikan perawatan pada bayinya. Kondisi ini berdampak pada sikap ketergantungan calon ibu terhadap orang-orang di sekelilingnya. Secarafisik, setelah menjalani proses persalinan kondisi perempuan memang cenderung lemah. Namun demikian,dalam beberapa hari diharapkan seorang ibu primipara bisa mulai terlibat dalam perawatan bayinya, termasuk memandikan bayi, mengganti pakaian bayi, merawat tali pusat bayi, memberikan ASI dan lain sebagainya.

Bidan sebagai provider layanan kebidanan, harus mampu memberikan suatu asuhan yang bermanfaat bagi para calon ibu sejak masa kehamilannya. Dengan demikian, primipara ini akan mampu merawat bayinya secara mandiri segera setelah bayilahir. Salah satukegiatan yang bias dilakukan oleh Bidan adalah melaksanakan konseling dan penyuluhan kesehatan melalui program Kelas Ibu Hamil dalam program KIA di wilayah kerja Puskesmas.

Kelas Ibu Hamil merupakan sarana untuk belajar bersama tentang kesehatan bagi ibu hamil, dalam bentuk tatap muka dalam kelompok. Kegiatan ini bertujuan untuk meningkatkan pengetahuan dan keterampilan ibu mengenai kehamilan, perawatan kehamilan, persalinan, perawatan nifas, perawatan bayi baru lahir, mitos seputar kehamilan, penyakit menular dan akte kelahiran bayi (Kemenkes, 2012).

Puskesmas Sukorame sebagai salah satu Puskesmas yang terletak di wilayah Dinas Kesehatan Kota Kediri, telah melaksanakan Program Kelas Ibu hamil ini sebanyak empat kali dalam setahun.
Jumlah sasaran ibu hamil pada tahun 2015 berjumlah 910 orang (Data Puskesmas Sukorame, 2015).

Program Kelas Ibu Hamil ini merupakan salah satu program kegiatan yang mendapat perhatian khusus dari Dinas Kesehatan setempat. Melalui program kegiatan Kelas Ibu Hamil, bidan dapat memberikan banyak pembelajaran yang lebih terarah dan mendukung upaya kemandirian ibu dalam perawatan kehamilan, persalinan dan perawatan bayi sehingga ibu mampu menentukan sikap berkenaan dengan hak reproduksinya secara mandiri. Penelitian ini bertujuan untuk mengetahui hubungan kelas ibu hamil terhadap kemandirian ibu primipara dalam perawatan neonatus.

\section{METODE PENELITIAN}

Penelitian ini merupakan penelitian analitik korelasional dengan pendekatan cross sectional. Populasi dalam penelitian ini adalah seluruh ibu hamil primigravida trimester III (usia kehamilan 29-40 minggu) di wilayah kerja Puskesmas Sukorame kota Kediri berjumlah 35 orang.

Sampel dalam penelitian ini adalah sebagian dari populasi yang memenuhi criteria inklusi, sebanyak 22 orang. Teknik sampling menggunakan metode purposive sampling.Variabel Independent dalam penelitian ini yaitu pelaksanaan kelas ibu hamil, sedangkan Variabel Dependent adalah Kemandirian ibu primipara dalam perawatan neonatus. Instrumen yang digunakan dalam penelitian ini adalah kuesioner untuk menilai pelaksanaan kelas ibu hamil dan lembarobservasi (ceklist) untuk menilai kemandirian ibu primipara dalam melakukan perawatan bayi di rumah. Untuk menguji hipotesis, digunakan fisher exact probablity test untuk taraf kesalahan $\alpha=5 \%$ 


\section{HASIL PENELITIAN}

\section{Pelaksanaan Kelas Ibu Hamil}

Hasil evaluasi pelaksanaan kelas ibu hamil dapat diamati dari tabel di bawah ini

Tabel 1 : Distribusi Pelaksanaan Kelas Ibu Hamil pada Responden

\begin{tabular}{clcc}
\hline $\mathbf{N}$ & KATEGOR & JUMLA & PERSENTAS \\
$\mathbf{O}$ & \multicolumn{1}{|c}{} & H & E $(\boldsymbol{\%})$ \\
\hline $\mathbf{1}$ & Kurang Baik & 6 & 27,3 \\
$\mathbf{2}$ & Baik & 16 & 72,7 \\
& Total & 22 & 100 \\
\hline
\end{tabular}

Berdasarkan tabel 1 diatas, setelah dilaksanakan evaluasi dalam kelas ibu hamil didapatkan bahwa sebagian besar responden memperoleh hasil baik, yaitu $72,7 \%$.

\section{Kemandirian Ibu Primipara Dalam Perawatan Neonatus}

Kemandirian ibu primipara dalam perawatan neonatus ditunjukkan pada tabel 2.

Tabel 2 Distribusi Kemandirian Ibu

Primipara Dalam Perawatan

Neonatus

\begin{tabular}{clcc}
\hline $\mathbf{N}$ & KATEGOR & JUMLA & PERSENTAS \\
$\mathbf{O}$ & I & H & $\mathbf{\text { \% } )}$ \\
\hline $\mathbf{1}$ & Kurang & 7 & 31,8 \\
& Mandiri & & \\
$\mathbf{2}$ & Mandiri & 15 & 68,2 \\
& Total & 22 & 100 \\
\hline
\end{tabular}

Berdasarkan tabel 2 diatas sebagian besar responden mandiri dalam merawat neonatusnya, yaitu sebesar $68,2 \%$.

Tabel 3 : Distribusi Kemandirian Ibu Primipara Dalam Perawatan Neonatus Berasarkan Tiap Parameter

\begin{tabular}{cccccccc}
\hline \multirow{2}{*}{$\begin{array}{c}N \\
\mathrm{o}\end{array}$} & Parameter & \multicolumn{2}{c}{$\begin{array}{c}\text { Kurang } \\
\text { Mandiri }\end{array}$} & Mandiri & \multicolumn{2}{c}{ Total } \\
\cline { 2 - 8 } & $\mathrm{f}$ & $\%$ & $\mathrm{f}$ & $\%$ & $\mathrm{f}$ & $\%$ \\
\hline 1 & Menyusui & 6 & 27,3 & 16 & 72,7 & 22 & 100 \\
\hline 2 & $\begin{array}{l}\text { Meman- } \\
\text { dikan }\end{array}$ & 12 & 54,5 & 10 & 45,5 & 22 & 100 \\
\hline 3 & $\begin{array}{l}\text { Perawatan } \\
\text { tali pusat }\end{array}$ & 17 & 77,3 & 5 & 22,7 & 22 & 100 \\
\hline 4 & $\begin{array}{l}\text { Pencega- } \\
\text { han } \\
\text { hipotermi }\end{array}$ & 10 & 45,5 & 12 & 54,5 & 22 & 100 \\
\hline & & & & & & &
\end{tabular}

Berdasarkan tabel 3, sebagian besar responden mandiri dalam memberikan ASI pada bayinya yaitu sebesar $72,7 \%$, Sebagian besar responden kurang Mandiri dalam memandikan neonatus yaitu 54,5\%. Sebagian besar responden kurang mandiri dalam perawatan tali pusat yaitu $77,3 \%$ dan sebagian besar responden mandiri dalam pencegahan hipotermi pada neonatus yaitu 54,5\%.

\section{Hubungan Pelaksanaan Kelas Ibu Hamil Terhadap Kemandirian Ibu Primipara Dalam Perawatan Neonatus}

Tabel 4Tabulasi silang pelaksanaan kelas ibu hamil dan kemandirian dalam perawatan neonatus

\begin{tabular}{clccc}
\hline & & \multicolumn{2}{c}{ Kemandirian ibu } & TOTAL \\
\cline { 3 - 4 } & & $\begin{array}{c}\text { Kurang } \\
\text { mandiri }\end{array}$ & mandiri & \\
Kelas & Kurang & 4 & 2 & 6 \\
ibu & baik & & & \\
hamil & baik & 3 & 13 & 16 \\
& TOTAL & 7 & 15 & 22 \\
\hline
\end{tabular}

Pada tabulasi silang diatas antara pelaksanaan kelas ibu hamil dan kemandirian ibu hamil didapatkan hasil bahwa sebagian responden yang hasil evaluasi kelas ibu hamil dalam kategori baik juga menunjukkan kemandirian dalam perawatan neonatusnya, yakni sebanyak 13 responden dari total 22 responden. Berdasarkan hasil hitung denganFisher's Exact probablity Testuntuk taraf kesalahan a 5\% $(0,05)$ didapatkanbahwaantara pelaksanaan kelas ibu hamil dengan kemandirian ibu hamil dalam perawatan neonatus, didapatkan $p$ (hitung) $=0,054$ lebih besar dari 0,05. Sehinggadapat disimpulkan bahwa harga $p$ (hitung) lebih besar dari taraf kesalahan yang ditetapkan, sehingga $\mathrm{H}_{0}$ diterima dan $\mathrm{H}_{1}$ ditolak.

\section{PEMBAHASAN \\ Pelaksanaan Kelas Ibu Hamil}

Berdasarkan hasil penelitian, didapatkan hasil bahwa sebagian besar responden melaksanakan kelas ibu hamil 
dengan kategori baik yaitu $72,7 \%$ dan sebagian kecil dengan kategori kurang baik yaitu sebesar 27,3\%. Hal ini menunjukkan bahwa sebagian besar ibu hamil telah mengikuti kelas ibu hamil dan telah merasakan manfaatnya sebagai salah satu upaya pemeliharaan kesehatan ibu selama kehamilan.

Kelas ibu hamil merupakan sarana untuk belajar bersama tentang kesehatan bagi ibu hamil, dalam bentuk tatap muka secara berkelompok yang bertujuan untuk meningkatkan pengetahuan dan ketrampilan ibu hamil mengenai kehamilan, persalinan, nifas, $\mathrm{KB}$, pencegahan komplikasi sampai pada perawatan bayi baru lahir sehari-hari.

Terdapat empat topik utama yang harus dikuasai oleh ibu hamil selama pelaksanaan kelas ibu hamil. Empat topik besar ini disampaikan dalam 4 kali pertemuan dan memuat berbagai informasi kesehatan yang sangat diperlukan oleh ibu hamil, yaitu : (1) pemeriksaan kehamilan agar ibu dan janin sehat, (2) Persalinan Aman, Nifas Nyaman, Ibu Selamat dan Bayi Sehat, (3) Pencegahan Penyakit, Komplikasi Kehamilan, Persalinan dan Nifas agar Ibu dan Bayi Sehat, serta (4) Perawatan Bayi Baru Lahir agar Tumbuh Kembang Optimal (Kemkes RI, 2012).

Tingginya pemahaman yang didapatkan ibu hamil selama mengikuti kelas ibu hamil ini, membuktikan bahwa keberadaan kelas ibu hamil merupakan sarana yang tepat untuk mendapatkan berbagai informasi kesehatan secara lebih mengarah. Sejauh ini, penyuluhan kesehatan atau pemberian informasi kesehatan ibu dan anak pada umumnya hanya diberikan melalui konsultasi perorangan atau kasus per kasus pada pertemuan posyandu dan pemeriksaan kehamilan saja. Dengan demikian, pengetahuan yang didapatkan oleh ibu hamil biasanya hanya terbatas pada masalah kesehatan yang dialami saja. Selain itu, tidak adanya rencana kerja tentang penyuluhan yang terkoordinir dengan baik, akan berakibat pada kesulitan petugas kesehatan dalam melakukan evaluasi terhadap keberhasilan penyuluhan yang telah diberikan.

Dengan demikian, kegiatan kelas ibu hamil ini merupakan kegiatan yang terencana dengan baik dan disusun dengan menerapkan berbagai metode pembelajaran, seperti tatap muka dalam kelompok, diskusi kelompok, demonstrasi dan tukar pengalaman nyata antara ibu hamil/ suami/ keluarga dan tenaga kesehatan. Kelas ibu hamil ini sangat mudah untuk diikuti karena telah memiliki perncanaan yang matang untuk setiap pertemuan. Materi pertemuan disampaikan secara sistematis dan menyeluruah, serta melibatkan tenaga kesehatan yang kompeten dalam penyampaian materi. Selain itu, penggunaan media belajar seperti buku KIA, flip chart dan alat peraga yang digunakan sesuai pembahasan materi, menjadi daya tarik tersendiri bagi kelompok ibu hamil yang terlibat dalam kelas ibu hamil. Dengan keberadaan berbagai fasilitas penunjang itu, ibu hamil akan merasa lebih mudah memahami dan mengaplikasilan

pengetahuan/ketrampilan yang diperoleh dalam kehidupan sehari-hari.

\section{Kemandirian Ibu Primipara Dalam Perawatan Neonatus}

Kemandirian merupakan kemampuan dalammengatur tingkah laku, menyeleksi dan membimbing keputusan serta perilakunya tersebut tanpa ada paksaan serta pengontrolan dari orang tua atau pengawasaan orang lain (Ryan \& Lynch, 2005). Dari pernyataan tersebut diatas, dapat disimpukan bahwa seoarng ibu hamil yang mandiri akan memiliki kemampuan untuk berdiri sendiri, tidak tergantung pada orang lain serta berhak menggali potensi diri sendiri untuk memenuhi kebutuhan dan mengatasi kesulitan. 
Hasil penelitian menunjukkan bahwa ibu hamil yang telah mengikuti kelas hamil ternyata sebagian besar telah memiliki kemandirian yang cukup dalam perawatan neonatus, yaitu sebesar $68,2 \%$

Adapun sebagian kecil (31,8\%) menunjukkan sikap kurang mandiri dalam perawatan neonatus sehari-hari.

Dalam penelitian ini, kemandirian ibu hamil dalam melaksanakan perawatan neonatus dikaji dari empat aspek, yaitu : (1) perawatan tali pusat bayi, (2) cara memandikan bayi, (3) pencegahan hipotermia pada bayi, serta (4) pemberian ASI ekslusif. Keempat aspek ini bisa didapatkan ibu hamil dari hasil pembelajaran kelas ibu hamil pada pertemuan terakhir atau pertemuan 4 . Berdasarkan data yang diperoleh, sebagian besar ibu hamil dinyatakan dengan kategori mandiri dalam hal pencegahan hipotermia dan pemberian ASI eklusif, yaitu sebesar $54,5 \%$ dan $72,7 \%$. Sedangkan untuk kedua aspek yang lain, yaitu aspek perawatan tali pusat dan memandikan bayi masih tergolong kategori kurang mandiri sebesar 22,7\% dan 45,5\%.

Kondisi ini bisa dimengerti mengingat masih kentalnya budaya sosial masyarakat yang masih memberikan peran penting pada dukun bayi atau nenek bayi dalam hal memandikan bayi dan perawatan tali pusat. Sebagaimana Lenner dalam Budiman (2006) berpendapat bahwa kemandirian hanya bisa dibentuk bila seseorang tidak terpengaruh pada lingkungan sosial dan dibiarkan bebas mengatur kebutuhannya sendiri. Dalam hal ini, Lenner juga menambahkan bahwa seseorang bisa menjadi sosok mandiri apabila mampu mengatasi hambatan, gigih dalam berusaha serta melakukan sendiri tanpa bantuan orang lain. Hal inilah yang dimungkinkan kurang mampu dilakukan oleh para responden sehingga masuk dalam kategori kurang mandiri.

Seorang ibu muda (primipara) lebih sering dihadapkan pada sistuasi yang sulit, dimana ia diperlakukan sebagai seorang ibu yang masih kurang dalam hal pengalaman, pengetahuan serta ketrampilan merawat bayinya. Apalagi dalam hal memandikan bayi dan perawatan tali pusat yang selama ini masih banyak dipercayakan kepada para orang yang lebih ahli, misalnya kakaknya atau orang tuanya yang sudah memiliki pengalaman dalam perawatan bayi. Mereka dianggap sebagai orang yang memiliki kemampuan utama dalam halmemandikan dan perawatan tali pusat.

Keluarga dari Ibu Primipara belum bisa mempercayakan perawatanbayi baru lahir pada ibunya secara langsung, karena menganggap ibu belum punya pengalaman dalam perawatan bayi baru lahir serta masih merasa kasihan karena ibu bayi masih dalam kondisi yang belum pulih dari proses persalinan. Terlebih lagi bila ibu muda tersebut masih tergolong kurang dalam hal usia, intelegensi dan tingkat pendidikan. Ketiga faktor ini memang merupakan faktor internal yang mempengaruhi kemandirian seseorang dalam bertindak (Musdalifah, 2007). Namun demikian, bila seorang ibu muda mendapatkan kesempatan untuk memperoleh pengetahuan yang cukup tentang proses yang sedang ia alami, hampir bisa dipastikan bahwa kemungkinan kecil ia akan mengalami kegagalan dalam menjalankan peran sebagai seorang ibu secara mandiri.

Faktor lain yang tidak kalah penting dalam pembentukan kemandirian ibu adalah faktor eksternal yang meliputi kebudayaan, pola asuh, pendidikan dan status ekonomi. Dari data responden didapatkan bahwa hanya 13,6\% responden yang berlatar belakang pendidikan Perguruan Tinggi, sedangkan sisanya hanya lulus Sekolah Dasar dan Sekolah Menengah. Sedangkan untuk data sosial ekonomi setidaknya bisa dilihat dari data pekerjaan responden yang sebagian besar sebagai ibu rumah tangga $(72,7 \%)$. 
Faktor lain yang belum terkaji adalah kebudayaan masyarakat setempat yang masih mempercayakan perawatan bayi pada dukun bayi. Namun demikian, dari data diatas, bisa pula kita simpulkan bahwa adanya kegiatan kelas ibu hamil mampu memberikan kontribusi positif terhadap kemandirian ibu dalam hal pencegahan hipotermia dan pemberian ASI ekslusif. Dua aspek yang tentunya membutuhkan pemahaman yang lebih tinggi jika dibandingkan dengan memandikan bayi dan perawatan tali pusat. Sadar atau tidak, sebagian besar responden telah mampu bersikap mandiri dalam dua aspek perawatan bayi ini, dengan berbekal pengetahuan yang didapatkan selama mengikuti kelas ibu hamil. Sehingga, besar kemungkinan bagi para ibu muda ini untuk mampu bersikap mandiri dalam hal memandikan bayi dan perawatan tali pusat, jika tidak ada pengaruh kuat dari kebudayaan setempat.

Hubungan pelaksanaan Kelas Ibu Hamil Terhadap Kemandirian Ibu Primipara Dalam Perawatan Neonatus Berdasarkan hasil hitung fisher exact probablity test untuk taraf kesalahan $\alpha$ $5 \%(0,05)$ antara pelaksanaan kelas ibu hamil dengan kemandirian ibu hamil dalam perawatan neonatus, didapatkan $p$ (hitung) adalah 0,054 lebih besar dari 0,05 . Dari perhitungan diatas dapat disimpulkan bahwa harga $p$ (hitung) lebih besar dari taraf kesalahan yang ditetapkan, sehingga $\mathrm{H}_{0}$ diterima dan $\mathrm{H}_{1}$ ditolak, yang berarti tidak terdapat hubungan antara pelaksanaan kelas ibu hamil dengan kemandirian ibu hamil dalam perawatan neonatus.

Hal ini tentu saja bertentangan dengan tujuan dilaksanakannya kegiatan kelas ibu hamil, bahwa salah satu harapan yang ingin dicapai adalah meningkatkan pemahaman, sikap dan perilaku ibu hamil tentang perawatan bayi baru lahir dan neonatus agar bisa menjalani tumbuh kembang secara optimal (Kemkes, 2012). Data yang didapatkan dari hasil penelitian ini menunjukkan bahwa bahwa terdapat hubungan positif antara pelaksanaan kelas ibu hamil yang baik dengan kemandirian ibu hamil dalam perawatan neonatus yaitu sebesar 59,1\%. Demikian pula dengan pelaksanaan kelas ibu hamil yang kurang baik juga disertai dengan kemandirian ibu yang kurang dalam perawatan neonatus, yaitu sebesar $18,2 \%$.

Namun demikian, berdasarkan uji fisher exact didapatkan bahwa tidak terdapat hubungan antara pelaksanaan kelas ibu hamil dengan kemandirian ibu hamil dalam perawatan neonatus. Kemungkinan penyebab utama diperolehnya hasil penelitian ini adalah karena jumlah responden yang digunakan sebagai sampel yang terlalu kecil sehingga dianggap tidak memenuhi kriteria untuk dilakukan uji chi square. Selain itu, adanya proses interaksi yang tidak efektif selama pelaksanaan kegiatan kelas ibu hamil, dinilai memberikan kontribusi yang cukup besar bagi kemandirian ibu hamil dalam perawatan neonatus. Interaksi ini meliputi interaksi antara ibu hamil dengan petugas kesehatan, keluarga maupun sesama anggota kelompok ibu hamil.

Dalam kegiatan kelas ibu hamil, sudah seharusnya peserta dituntut untuk mampu menyampaikan pendapat serta ide-ide terkait dengan pengalaman masing-masing selama menjalani proses kehamilan. Selain itu, mereka juga diharapkan bisa melibatkan anggota keluarga untuk berperan aktif dalam perawatan ibu selama proses kehamilan, persalinan, nifas dan perawatan neonatus. Semakin banyak keluarga yang terpapar dengan pengetahuan yang tepat tentang perawatan neonatus, maka akan semakin kecil kemungkinan ibu dan keluarga tersebut untuk tergantung pada dukun bayi dalam perawatan neonatus seharihari. Dengan demikian bisa meminimalkan pengaruh penggunaan adat istiadat atau kebudayaan masyarakat yang tidak sesuai dengan prinsip kesehatan, seperti memberikan 
bobok/ramuan daun-daunan pada saat perawatan tali pusat.

Namun demikian, harapan dari pelaksanaan kegiatan ini tentu saja tidak akan terwujud apabila ibu hamil sebagai peserta dan keluarga sebagai pendamping tidak mau berperan serta secara aktif untuk mengikuti kegiatan yang telah direncanakan. Demikian pula bila tenaga kesehatan sebagai fasilitator tidak mampu memandu jalannya interaksi antar peserta kelas ibu hamil dengan baik. Keterbatasan interaksi ini bisa dipengaruhi dari ketidakmampuan ibu hamil dan keluarga dalam menyampaikan pendapat, ide dan pengalaman pribadi oleh karena keterbatasan pengetahuan yang dimiliki. Terlebih jika dilihat bahwa sebagian besar responden $(86,4 \%)$ hanya berlatar belakang pendidikan sekolah dasar dan menengah. Selain itu, status responden yang baru pertama kali hamil juga menjadi salah satu penyebab keterbatasan responden dalam berbagi pengalaman saat interaksi kelas ibu hamil berlangsung. Ibu hamil tidak akan mampu bercerita banyak jika tidak mengalami secara langsung mengenai topik yang dibahas, misalnya pengalaman pertama saat menyusui. Bagi ibu hamil primigravida, tentunya akan mengalami banyak kesulitan dalam menyampaikan ide/pendapat terkait hal tersebut karena belum pernah merasakan secara langsung. Oleh karena itu, kehadiran tenaga kesehatan sebagai fasilitator diharapkan mampu membuka wawasan ibu dengan penggunaan berbagai metode yang mudah dipahami mengenai proses laktasi, walaupun peserta kelas ibu hamil belum pernah mengalami proses ini secara nyata.

Kebutuhan ibu hamil untuk melakukan interaksi dengan orang-orang serta lingkungan yang tepat akan membentuk sikap mandiri yang sangat diperlukan pada perawatan neonatus. Sebagaimana Antonius (dalam Fatimah, 2003) menyebutkan bahwa diri-ciri sikap mandiri bisa ditunjukkan dari perilaku/tindakan terbaik yang akan selalu ditampilkan ibu hamil selama merawat bayi mereka, berorientasi pada tujuan kesehatan bayi dengan tetap memperhatikan proses belajar selama mengikuti kelas ibu hamil, serta berusaha mewujudkan aktualisasi diri sebagai ibu yang ideal bagi bayi yang baru saja dilahirkan. Dengan demikian, semakin baik proses persiapan ibu selama kegiatan kelas ibu hamil, maka diharapkan akan semakin mandiri pula ibu dalam melakukan perawatan neonatus seharihari. Hal ini berarti, akan semakin berkurang pula ketergantungan ibu terhadap orang lain sehingga bisa berperan optimal dalam menyertai putra/putri mereka selama proses tumbuh kembangnya.

\section{KESIMPULAN}

Berdasarkan hasil penelitian maka peneliti dapat mengambil kesimpulan sebagai berikut: (1) Sebagian besar responden memiliki hasil yang baik dari pelaksanaan kelas ibu hamil; Sebagian besar responden memiliki kemandirian dalam melakukan perawatan neonatus; (3) Pelaksanaan kelas ibu hamil tidak ada hubungannya dengan kemandirian ibu dalam melakukan perawatan pada neonatus.

\section{SARAN}

Berdasarkan kajian pada hasil penelitian, maka peneliti memberikan saran: (1) Bagi Peneliti Selanjutnya, Perlu dilakukan penelitian dengan menggunakan sampel yang lebih besar wilayah penelitian yang lebih luas; (2) Bagi Institusi, diharapkan dapat menambah wawasan bagi peneliti berikutnya dan dapat digunakan sebagai bahan pertimbangan penelitian. Institusi juga dapat memiliki motivasi untuk dapat membuka kelas bagi Orang Tua/Calon Orang Tua, sehingga akan lebih bermanfaat bagi masyarakat sekitar; (3) Bagi Tempat Penelitian, hasil penelitian ini dapat dipakai sebagai acuan dan 
motivasi untuk tetap melaksanakan Kelas ibu Hamil secara rutin dan melibatkan para Kader pada pelaksanaan Kelas Ibu hamil di Puskesmas.

\section{DAFTAR PUSTAKA}

Ali, Zaidin. 2010. Dasar - Dasar Pendidikan Kesehatan Masyarakat Dan Promosi Kesehatan. Jakarta: Trans Info Media.

Bappenas, 2010.Pedoman Pelaksanaan Kelas Ibu Hamil. Jakarta: Bappenas

Budioro. 2007. Pengantar Pendidikan (Penyuluhan) Kesehatan Masyarakat. Semarang: Badan Penerbit UNDIP.

Cunningham, F. Gary dan Gant, Norman F. 2010. Dasar - Dasar Ginekologi Dan Obstetri. Jakarta: EGC.

Dalyono. 2005. Psikologi Pendidikan. Jakarta: Rineka Cipta.

Dinkes Jatim. 2012. Profil Kesehatan Provinsi Jawa Timur Tahun 2012. Surabaya: Dinkes Prov Jatim diakses 28-1-2015 melalui http://dinkes.jatimprov.go.id

Direktorat Kesehatan Anak Khusus. 2010. Panduan Pelayanan Kesehatan Bayi BaruLahir Berbasis Perlindungan Anak. Jakarta: Kementerian Kesehatan Republik Indonesia.

Fatimah, E. 2006. Psikologi Perkembangan. Bandung : CV Pustaka Setia

Hamilton, P. 2011. Dasar-dasar keperawatan maternitas. Jakarta : EGC.

Hidayat,A. (2010). Metode Penelitian Kebidanan dan Teknik Analisis Data. Salemba Medika, Surabaya

Hurlock, E. B. 2000. Psikologi Perkembangan. Jakarta : Erlangga

Kasdu Dini. 2012. Perawatan Bayi Baru. Jakarta: Batavia Press.

Kemenkes.2012. Pedoman Pelaksanaan kelas Ibu Hamil. Jakarta: Kesehatan Kementrian RI

Kemenkes. 2013. Profil Kesehatan Indonesia 2012. Jakarta: Kesehatan
Kementrian RIdiakses 28-1-2015 melalui http://www.kemkes.

Musdalifah.2007. Perkembang aja dalam Kemandirian lewmu Psikologis dependensi terhadap orang tua). Jurnal Pendidikan dan Psikologi Perkembangan. Vol 4.

Notoatmodjo, Soekidjo. 2011. Kesehatan Masyarakat. Jakarta: Rineka Cipta. 2012. Metodologi Penelitian

Kesehatan. Jakarta: Rineka Cipta.

Nursalam. 2008. Konsep Dan Penerapan Metodologi Penelitian Ilmu Keperawatan. Jakarta: Salemba Medika.

Prawirohardjo, S. 2009. Ilmu kebidanan. Jakarta : PT. Bina Pustaka Sarwono Prawirohardjo.

Saifuddin, A. 2009. Buku acuan nasional pelayanan kesehatan maternal dan neonatal. Jakarta : PT. BPSP.

Simkin, P. 2010. Panduan lengkap kehamilan, melahirkan, dan bayi. Jakarta : Arcan.

Sugiyono. 2011. Metode penelitian kuantitatif kualitatif dan $R \& D$. Bandung: Alfabeta. 2012.Statistika Untuk Penelitian.

Bandung: Alfabeta.

Syafrudin dan Fratidhina, Yudhia. 2009. Promosi Kesehatan Untuk Mahasiswa Kebidanan. Jakarta: Trans Info Media.

Syafrudin, dkk. 2011. Himpunan Penyuluhan Kesehatan. Jakarta: Trans Info Media.

Varney, H. 2007. Buku ajar asuhan kebidanan. Jakarta : EGC

Yusuf. 2001. Psikologi Perkembangan Anak dan Remaja. Bandung: PT. Remaja Rosda

Widyasih, dkk. 2012. Perawatan Masa Nifas. Yogyakarta: Fitramaya 